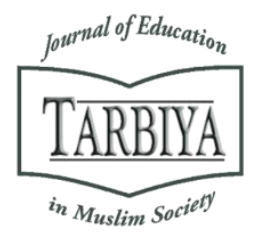

Available online at TARBIYA: Journal of Education in Muslim Society Website:

http://journal.uinjkt.ac.id/index.php/tarbiya

TARBIYA: Journal of Education in Muslim Society, 3(2), 2016, 168-185

\title{
ASSESSING THE MORAL CREDENTIALS OF THE NEXT GENERATION OF ACCOUNTANTS
}

\author{
Umaru Zubairu, Olalekan Sakariyau, Chetubo Dauda, Isah Paiko \\ Federal University of Technology Minna, Nigeria \\ E-mail: uzubairu@gmail.com
}

Received: $11^{\text {th }}$ October 2016; Revised: $11^{\text {th }}$ November 2016; Accepted: $28^{\text {th }}$ December 2016

\section{Abstract}

This study assessed the progress of Malaysian universities in producing morally upright accountants by evaluating the moral competencies of the third-year accounting students enrolled at the Universiti Sains Islam Malaysia (USIM). An instrument was developed through a collaboration with Islamic accounting scholars; 79 third-year students were surveyed. The survey revealed that the current crop of the third-year accounting students were not morally competent enough to deal with the inevitable moral dilemmas they would face in the work place. The implication of this result is that USIM's accounting department has to re-examine its current curriculum as to its ethics coverage.

Keywords: moral competence; accounting students; university education; ethics education; Islamic perspective

\begin{abstract}
Abstrak
Penelitian ini bertujuan untuk menilai perkembangan universitas-universitas di Malaysia dalam hal menghasilkan para akuntan yang jujur. Penelitian ini dilakukan dengan langkah mengevaluasi kompetensi moral mahasiswa akuntansi tahun ketiga di Universiti Sains Islam Malaysia (USIM). Instrumen yang digunakan adalah survey, yang dikembangkan melalui kolaborasi para cendekiawan muslim dengan mensurvey 79 mahasiswa tahun ketiga. Hasil survey menunjukkan bahwa para siswa tahun ketiga akuntansi pada zaman sekarang ini belum memiliki kompetensi moral dalam hal dilemma moral pada bidang pekerjaan mereka. Implikasi penelitian ini adalah berupa saran untuk jurusan akuntansi USIM untuk menguji kembali kurikulum mereka yang berkenaan dengan etika dan moral.
\end{abstract}

Kata kunci: kompetensi moral; mahasiswa akuntansi; pendidikan tinggi; pendidikan etika; perspektif Islam

How to Cite : Zubairu, U. Sakariyau, O. Dauda, C. Paiko, I. (2016). Assessing the Moral Credentials of the Next Generation of Accountants. TARBIYA: Journal of Education in Muslim Society, 3(2), 168-185.

doi:10.15408/tjems.v3i2.4166.

Permalink/DOI: http://dx.doi.org/10.15408/tjems.v3i2.4166

Copyright $\odot$ 2016, TARBIYA: Journal of Education in Muslim Society,

P-ISSN: 2356-1416, E-ISSN: 2442-9848 


\section{Introduction}

In the earliest part of the twenty-first century, the world was rocked by several financial scandals; from Enron to WorldCom; Tyco to Parmalat; Arthur Andersen to Shell, and more recently, the global financial crisis and the Toshiba financial scandal (Bayou et al., 2011; Addady, 2015); these scandals directed the world's attention towards the issue of ethics education, and its role in developing the moral competencies of future accountants and corporate leaders.

The concern about the rampant increase in immoral practices of accountants and businessmen was not restricted only to America and Europe; there was also concern in Malaysia (Abu Bakar et al., 2010; Yunus and Abdul Rashid, 2011; Eid, 2012). In order to address this alarming increase in unethical and immoral behaviours among business people in Malaysia, the government focused on the educational sector as a viable mechanism for checking this growing menace. This is evidenced by a 2012 blueprint to overhaul the Malaysian educational system within thirteen years (Malaysia Education Blueprint 2013-2025, 2012). This blueprint had eleven key objectives, one of which was directly targeted to the issue of moral competence amongst young Malaysians, and was stated as follows: "Every student leaves school as a global citizen imbued with core, universal values and a strong Malaysian identity. The values they have learnt are applied in their day to day lives, leading to more civic behaviour such as an increase in volunteerism; a willingness to embrace peoples of other nationalities, religions and ethnicities; and a reduction in corruption and crime. Every student also leaves school prepared to act as a leader, whether in their own lives and families, or as part of the broader community and nation" (Malaysia Education Blueprint 2013-2025, 2012, p34).The
Malaysian government's message to all educational institutions in Malaysia regarding moral competence is clear: Produce students who have excellent moral values and ethics.

Three years have passed since the government's 2012 mandate to universities for the production of morally competent professionals. This paper sought to shed light on how well Malaysian universities are fulfilling this crucial mandate specifically regarding future accountants by assessing the moral competencies of third-year accounting students enrolled at the Universiti Sains Islam Malaysia (USIM). With $61.3 \%$ of the Malaysian population being Muslims, accounting students enrolled at USIM represent a sample of the majority of the next generation of Malaysian accountants. As this paper dealt exclusively with Muslim accounting students, moral competence was viewed from a wholly Islamic perspective with complete reliance on Islam's primary sources of guidance: The Noble Quran and Sunnah of the Prophet Muhammad (Peace be upon him [PBUH]).

The rest of the paper proceeds as follows: Firstly, a literature review of the scholarship on the relationship between university education and moral competency is presented. Secondly, this paper's conceptual framework is presented, followed by the research methodology adopted. The findings of the paper are then presented, along with a discussion of their implications. Finally, the paper ends with a conclusion.

The papers reviewed were concerned with the relationship between various aspects of education and the development of the moral competence. Specifically there were three key concerns: 1) The impact of education in general on moral competence, 2) The impact of "ethics" education on moral competence, and 3) A description of the "optimum" content of ethics education. An overview of each of these concerns is provided below. Additionally, the Islamic 
position on the role of education in moral competence development is also provided.

\section{The impact of education on moral competence}

Swiss psychologist and philosopher, Jean Piaget was arguably one of the most influential proponents of the importance of education in the moral development of individual, particularly those children (Rest, 1989). In his 1932 landmark work entitled "The Moral Judgment of the Child", he sought to investigate the moral developmental process of children by interviewing a large number of children from various schools in the Swiss towns of Geneva and Neuchatel. The results of these interviews led to the postulation of a theory of child moral development that consisted of four developmental stages: The first stage was called sensorimotor stage; at this stage, children from birth to age two were focused only on themselves and were incapable of considering the welfare of others. At the second stage called the preoperational stage, children ages two to seven are still predominantly concerned only about themselves, but begin to develop an understanding of the welfare of others as well. The concrete operational stage follows whereby children aged seven to eleven became more logical in their thinking, and were no longer concerned only about themselves. At the fourth and final stage (formal operational stage), children from eleven and older were now able to think in abstract and holistic terms regarding issues of morality. Piaget (1932) concluded that children's morality is shaped by what they observe, and thus educational institutions have a critical role to play in their moral development by providing an interactive learning environment.

Lawrence Kohlberg, an American psychologist, built upon the work done by Piaget (1932). Kohlberg (1958) argued that the main goal of education should be moral development. He sought to assess the impact of education on the moral development of children of ages 10-16 by assessing their responses to various moral dilemmas. The major fruit of his research was the postulation of the now very famous "stages of moral development". Kohlberg's (1958) theory of moral development identified six stages of moral development, classified under three levels, each level containing two stages. The first level is called the pre-conventional level containing stages 1 and 2 ; at stage 1 , a child acts morally so as to avoid punishment, while at stage 2 , he or she acts morally to earn a reward. The next level is the conventional level containing stages 3 and 4; at stage 3, a child acts in a way that is accepted by society, and at stage 4 a child obeys the established laws of the land. The final level is the post-conventional level containing stages 5 and 6 ; at stage 5 , a child chooses actions that will benefit the majority (this is similar to the utilitarian rule of ethics), and at stage 6 , a child acts based on universal principles.

Rest (1986) followed in the footsteps of his mentor, Kohlberg, by theorizing that if educators were to effectively enhance the moral development of students, they had to understand the psychological processes that needed to take place for moral action to occur. He developed a four-component model of ethical behaviour to explain these processes. The first component was moral sensitivity which is the recognition of the existence of an ethical problem; then, the second component was moral judgment which is making determination of the right course of action to take in that specific ethical context; Next, the third component, moral motivation refers to the strength of an individual's conviction to actually follow through with the right course of action identified through his moral judgment; and the last component, moral character represents the actual implementation of the chosen course of action. Rest (1986) 
argued that by understanding these four components, educators could develop ethics curricula that would enhance each of these components, and thus improve the moral competencies of students.

After these landmark pieces of scholarship by Piaget (1932), Kohlberg (1958) and Rest (1986), several studies have sought to empirically test the role of a university education on the moral competencies of students. A majority of these studies, Chafi's (2013) and Özdemir et al.'s (2015) studies being the only dissenting voices, provided evidence to support the assertion that education, regardless of the level, has a positive impact in developing students' moral competencies (Liaquat et al., n.d., Al-Ansari, 2002; Schillinger, 2006; Thomas, 2012; Clipa and Iorga, 2013; Doyle and O’Flaherty, 2013). Moral development was more pronounced in students of the humanities than those involved in technical disciplines (Lofstrom, 2012; Lajciakova, 2013).

\section{The Impact of "ethics" education on moral competence}

Unlike studies in the section above that focused on the impact of education in general on moral competence, those reviewed in this section focused on determining the impact of ethics education, be it a stand-alone ethics course or integrated ethics coverage within the curriculum, on the moral competencies of students. A review of these studies revealed that the results were mixed, with some studies finding a positive relationship between ethics education and moral competence (Sullivan, 2004; Dellaportas, 2006; Abdulmohammadi \& Baker, 2007; Bosco et al., 2010; Saat et al., 2010; Pleban et al., 2011; Holmes et al., 2012), and others finding no significant relationship between these two concepts (Altmyer et al, 2011; Chaganti, 2012; Padia \& Maroun, 2012; May \& Luth, 2013; Self et al., 2013).

\section{The "optimum" content of ethics education}

Despite mixed results regarding the effectiveness of ethics education in improving students' moral competence as evidenced by the studies reviewed in the previous section, papers reviewed in this section all had the basic assumption that ethics education was indeed effective in improving moral competence. Their concern was in "optimum" content for effective ethics education. Three distinct suggestions by scholars were observed; the first group advocated discipline-specific dilemmas as optimum (Titus et al., 2011; Schmidt et al., 2013). The second group advocated inclusion of "emotion laden" scenarios (Fontaine et al., 2012; Thiel et al., 2013 and Grezo and Pilarik, 2013), while the third group advocated a combination of the "Socratic Method" and "Reflective Teaching" (Wortel and Bosch, 2011; Kavathatzopoulous, 2012; Montgomery and Walker, 2012; and Kwok and Selman, 2013). A brief discussion of each of these groups follows in the subsequent paragraphs.

The first group that advocated disciplinespecific scenarios argued that the Rest's Defining Issues Test, which is the most commonly utilized instrument in moral competence scholarship, was too abstract and did not capture the realities of the dilemmas faced by specific professions. Each profession had to develop ethical scenarios that mirrored those that would actually be faced by their practitioners in the work environment.

The second group of scholars argued that ethical scenarios that evoked an emotional response from students would be most effective for enhancing students' moral competence. Fictional stories full of strong emotional cues and visuals would provide students with a wider and more enjoyable experience of ethical issues.

The third group advocated a combination of the "Socratic Method" and "Reflective Teaching". The "Socratic Method" is based on 
the work of renowned Greek philosopher Socrates and states that the best way to acquire knowledge and insight is through dialogue (Wortel and Bosch, 2011). "Reflective teaching" occurs when students are taught that resolving moral dilemmas is not limited to the use of logic alone, but to the use of one's internal belief system as well (Montgomery and Walker, 2012).

\section{Islamic position on the relationship between education and moral competence}

From an Islamic perspective, the relationship between education and moral competence is a pivotal one. This is evidenced by the fact that the first revealed verses of the Noble Qur'an emphasize this relationship as follows: Read in the name of your Lord who created. He created man from a clot. Read and your Lord is Most Honourable. Who taught to write with the pen. Taught man what he knew not (al-Alaq: 15). In addition, the Noble Prophet Muhammad (PBUH) also emphasized the importance of seeking knowledge in the following hadith narrated by Abu Hurairah, "I heard the Messenger of Allah (PBUH) saying: 'This world is cursed and what is in it is cursed, except the remembrance of Allah (dhikr) and what is conducive to that, or one who has knowledge or who acquires knowledge.”' (Sunan Ibn Majah, Vol. 1, Book 37, Hadith 4112).

In Islam, there is no distinction between education and ethics education. All courses of study must be done "in the name of Allah". Additionally, regarding the optimum content of education, Muslims are required only to seek beneficial knowledge which brings them closer to Allah. The Prophet (PBUH) informs of this fact in the following hadith narrated by Jabir, the Messenger of Allah said: 'Ask Allah for beneficial knowledge and seek refuge with Allah from knowledge that is of no benefit." (Sunan Ibn Majah, Book 34, Hadith 17).
The ultimate objective of seeking knowledge in Islam is to develop the fear of Allah and thus worship $\mathrm{Him}$ as $\mathrm{He}$ ought to be worshipped. Allah informs us of this in the $28^{\text {th }}$ verse of Surah Fatir as follows: And among people and moving creatures and grazing livestock are various colours similarly. Only those fear Allah, from among His servants, who have knowledge. Indeed, Allah is Exalted in Might and Forgiving.

\section{Conceptual Framework}

As previously discussed, the sole focus of this study was on future Muslim Accountants, which are identified as third-year Muslim accounting students enrolled at USIM. For this reason the concept of moral competence was considered from a wholly Islamic perspective, which is to say from the concept of The Noble Qur'an and Sunnah. Thus, a morally competent Muslim accountant was defined as one who has the ability to make moral decisions in line with the commands of Allah in the Noble Qur'an, and in accordance with the Sunnah of the Noble Prophet Muhammad (PBUH), in discharging his or her duties as an accountant.

In Islam, this concept of moral competence is made up of two separate but interdependent parts: 1) doing the right thing (moral action), and 2) doing the right thing for Allah's sake alone (moral intention). In the sight of Almighty Allah, a moral action is only acceptable if the moral intention is solely for His pleasure. The Blessed Prophet Muhammad (PBUH) explains this very important point in the famous hadith narrated by Umar bin Al-Khattab: The Messenger of Allah (PBUH) said, "The deeds are considered by the intentions, and a person will get the reward according to his intention. So whoever emigrated for Allah and His Messenger, his emigration will be for Allah and His Messenger; and whoever emigrated for worldly benefits or for a woman to marry, his emigration would be for what he emigrated for" (Riyad as- 
Salihin, Book 1, Hadith 1). This is a very crucial concept which this study took into consideration when assessing the moral competencies of Malaysia's future Muslim accountants. Figure 1 below illustrates the above mentioned conceptualization of moral competence.

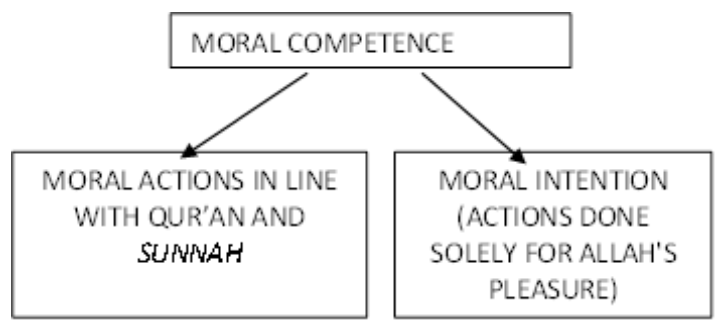

Figure 1: Conceptualization of Moral Competence

\section{Method}

This section of the paper presents the study's research design and methodology. Firstly, an overview of USIM is provided, with particular emphasis on the accounting department from which the students that participated in the study belong to. Secondly, the steps followed to develop a profile of a morally competent Muslim accountant are presented. Thirdly, the steps followed to develop the instrument to measure the moral competencies of Muslim accounting students are presented. Finally, the actual procedure adopted for measuring the moral competencies of the specified students is discussed.

An overview of the Universiti Sains Islam Malaysia (USIM): USIM was approved by the Malaysian cabinet on $11^{\text {th }}$ June, 1997, and officially opened on $13^{\text {th }}$ March, 1998. USIM adopts the philosophy that Islamic principles should serve as the foundation of all academic knowledge and has as its mission the utilization of the latest technologies and innovation to improve the lives of the Muslim ummah (brotherhood). USIM currently has 8 faculties and 4 centres of excellence. Of particular interest to this study is USIM's Bachelor of Accounting with Honours department which is in the process of securing Malaysian Institute of Accounting (MIA) accreditation and according to USIM is based entirely on Islamic teachings (Universiti Sains Islam Malaysia, 2014). At the time this study, USIM department of accounting had 10 academic staff and 454 undergraduate students enrolled.

Third-year USIM accounting students were selected for this study for two reasons: Firstly, these students have been in the system for three years, and thus the impact of USIM's accounting curriculum would have taken a significant effect on their moral competencies. Secondly, as these students still had one more year before graduation, whatever deficiencies in moral competency that this study discovered could be addressed and rectified by USIM's accounting department before these students graduated.

\section{Developing the Profile of the morally competent Muslim accountant}

This section described the process adopted in order to develop the profile of a morally competent Muslim accountant. The profile was developed from the perspective of the Muslim accounting graduate, and was divided into two components: 1) Finding the "right" job, and 2) Following an Islamic "code of conduct". A discussion of these two components is presented below

\section{Finding the "right" job}

Nu'man b. Bashir (Allah be pleased with him) reported: I heard Allah's Messenger (PBUH) as having said this (and Nu'man) pointed towards his ears with his fingers): What is lawful is evident and what is unlawful is evident, and in between them are the things doubtful which many people do not know. So he who guards against doubtful things keeps his religion and honour blameless, and he who 
indulges in doubtful things indulges in fact in unlawful things, just as a shepherd who pastures his animals round a preserve will soon pasture them in it. Beware, every king has a preserve, and the things God has declared unlawful are His preserves. Beware, in the body there is a piece of flesh; if it is sound, the whole body is sound and if it is corrupt the whole body is corrupt, and hearken it is the heart (Sahih Muslim 1599a, Book 22, Hadith 133).

For the Muslim accounting graduate, the first challenge that faces him or her is finding the "right" job. The "right" job is one where all activities are in line with the Qur'an and Sunnah. As the hadith above teaches us, the permissible jobs are clear and the prohibited jobs are clear, and the morally competent Muslim accountant must be able to make this distinction. The permissible activities are numerous in number, and thus the Muslim accountant has many options. Say, "My Lord has only forbidden immoralities - what is apparent of them and what is concealed - and sin, and oppression without right, and that you associate with Allah that for which He has not sent down authority, and that you say about Allah that which you do not know"(Al-Araf: 33). However, there are certain kinds of jobs the Muslim accountant has to avoid because the activities that they engage in are incompatible with the commands of Almighty Allah. ... And cooperate in righteousness and piety, but do not cooperate in sin and aggression. And fear Allah; indeed, Allah is severe in penalty (Al-Maeda: 2). Some of the most commonly known haram activities include i) dealing in interest, ii) gambling, and iii) dealing with intoxicants.

After securing a job at an Allah-approved organization, the next concern for the morally competent Muslim accountant is to fulfil his or her duties in accordance with the commands of Almighty Allah. This "Code of Conduct" represented the second component of the profile.

\section{Following an Islamic Code of Conduct}

As mentioned already in previous parts of this study, every act of a morally competent Muslim must be done with the objective of earning the pleasure of The Most Gracious Allah. A Muslim accountant must thus keep this critical objective in mind whilst discharging his or her duties as an accountant. The objective of this component of the profile was to develop a comprehensive Islamic code of conduct that includes all the qualities that a morally Muslim accountant must display in order to please his Creator. In order to develop this code of conduct for Muslim accountants, the study adopted a two-pronged approach.

The first prong was to adopt the code of conduct for Muslim accountants developed by the Accounting and Audit Organization for Islamic Financial Institutions (AAOIFI) as a foundation for this component of the profile. AAOIFI's code of conduct for Muslim accountants was published in 1991 and is derived from the Noble Qur'an and Sunnah; this made it an excellent starting point. AAOIFI's code of conduct contains five ethical principles described below: (1) Trustworthiness: The Muslim accountant should be straightforward and honest whilst discharging his duties, and must never present untruthful information. (2) Objectivity: The Muslim accountant should be fair, impartial and free from any conflict of interest. (3) Professional competence and diligence: The Muslim accountant must possess the requisite skill necessary to successfully discharge his duties. (4) Confidentiality: The Muslim accountant must never divulge information obtained about an organization during the course of discharging his or her duties without permission unless he or she is legally or professionally obliged to do so. (5) Professional conduct and technical standards: The Muslim accountant must observe the rules of professional 
conduct and obey the accounting and auditing standards of Shariah-compliant organizations.

The second prong was to interview and consult extensively with five Islamic scholars well versed in the Qur'an and Sunnah, particularly in the areas of "Islamic accounting" as well as "Fiqh Mu'amalat" (Laws of Islamic business transactions). These consultations established the content validity of AAOIFI's code of conduct. In addition to the five qualities listed by AAOIFI's code of conduct, the scholars suggested that three more qualities be added under the umbrella of "Faith-Driven" conduct, which are unique to the Muslim accountant. These qualities included (1) Avoiding interest, (2) Avoiding gambling, and (3) Avoiding physical contact with the opposite sex (non-mahram).

In total the developed profile of the ideal Muslim accountant had nine key qualities listed below: (1) Choosing the right job (2) Trustworthiness (3) Objectivity (4) Professional competence and diligence (5) Confidentiality (6) Professional conduct and technical standards (7) Avoiding interest (8) Avoiding gambling (9) Avoiding physical contact with the opposite sex.

After the development of the twocomponent profile of a morally competent Muslim accountant was completed, the next step was to develop an instrument capable of effectively measuring the nine qualities contained in the profile

\section{Developing the Muslim Accountant Moral Competency Test (MAMOC)}

A collaborative effort with five Islamic accounting and Fiqh Mu'amalat scholars resulted in the development of nine interrelated ethical scenarios to measure each of the nine qualities of a morally competent Muslim accountant highlighted above. The instrument thus developed is called "The Muslim
Accountant Moral Competency Test" or "MAMOC".

MAMOC had a title and three main sections: The instrument was titled "Understanding the Career Aspirations and Work-Related Decisions of Future Accountants". In order to minimize social desirability bias amongst the respondents, the study's objective was disguised by giving the instrument this neutral heading without any obvious moral overtones. The first section was a demographic section. The second section was titled "Choosing your dream job". Here, the respondents were given a choice of five job offers from companies in different industries. Each job offer had a company description, a job description and an annual salary. This section sought to determine if the Muslim accounting students knew what the right job was from an Islamic perspective. To test this important aspect of the students' moral competencies, all the jobs offered were unacceptable from an Islamic perspective; It was expected that the morally competent student would recognize this, and consequently reject all job offers on the basis of their unacceptability Islamically. The third section was titled "Living your dream job", and contained eight ethical scenarios, with each scenario testing each of the eight qualities of a morally competent accountant motioned earlier [(1) Trustworthiness (2) Objectivity Professional competence and diligence (4) Confidentiality (5) Professional conduct and technical standards (6) Avoiding interest (7) Avoiding gambling (8) Avoiding physical contact with the opposite sex]. The protagonist in the scenarios was a friend of the respondent, and the respondent was required to resolve the ethical dilemmas by advising his or her friend on what to do. The scenarios were structured in this way with the hope that respondents would be more honest in their answers if they were placed in an advisory capacity, rather than as the main actors 
in the scenarios. To conclude the instrument, the students were asked whether would remain with the company after all the experiences contained in the previous scenarios.

The ethical scenarios contained in the instrument were then resolved by the scholars based on evidence from the Qur'an and Sunnah. Their solution served as the model answer to each scenario, and also served as a scoring guide for determining the moral competencies of the students surveyed.

A pilot study was carried out using the newly developed instrument to assess whether respondents would understand the instructions, terminology and content of the questionnaire. Additionally, the pilot study enabled the researcher to ascertain the reliability of the scoring system developed by the Islamic scholars. 1st-year Muslim students from the Economics and Management Faculty at the International Islamic University Malaysia were used to conduct the pilot study. These students were enrolled in four different sections of a Financial Accounting Fundamentals class, and were selected because they closely resembled the students selected for the actual study, third-year Muslim accounting students. 100 questionnaires were distributed, and the students were asked to carefully go through the questionnaire and ask any questions they might have as to its content. All the students stated that they clearly understood how to fill the questionnaires. The students were then told to take the questionnaires home, complete them, and bring them to the next class session. They were also told to write down how long it took them to complete the questionnaire. 33 out of the 100 distributed questionnaires were returned.

An analysis of the completed questionnaires revealed that the students did indeed understand how to fill them. They provided well-thought out and clear resolutions to the various scenarios, and followed the stated instructions very well. The fact that first-year students could understand the instructions, content and terminology of MAMOC so well provided the researchers with confidence that the actual respondents of the study, third-year accounting students at USIM, would understand just as well.

Savulescu et al. (1999) explain that any instrument that is to be used to measure moral competence must be capable of being reliably applied by different raters. They also suggested that "naïve" raters should be utilized (naïve raters are those not involved in the development of the instrument). Following Savulescu et al.'s (1999) advice, after the pilot study was completed, the inter-rater reliability of the scoring system was assessed using the completed questionnaires from the pilot study; Inter-rater reliability is defined as the degree to which different judges or raters agree in their assessment decisions" (Phelan \& Wren, 2006). One of the researchers and one naive rater used the model answers to assess the moral competencies of the students that participated in the pilot study. Halgren (2012) stated that Intra-Class Correlation (ICC) is the most commonly used statistical procedure to determine inter-rater reliability for studies that have two or more raters, with continuous variables. SPSS was used to calculate the instrument's inter-rater reliability using ICC. High ICC values indicate greater inter-rater reliability, with an ICC estimate of the 1 indicating perfect agreement and 0 indicating only random agreement. Negative ICC estimates indicate systematic disagreement between the raters (Halgren, 2012). After the completed pilot study questionnaires had been rated by one of the researchers and the naive rater, an Intra-Class correlation coefficient of 0.943 showed that the two raters had an almost perfect agreement when assessing the moral competencies of the pilot study participants. This result proved the 
reliability of the model answer for assessment of students' moral competencies.

Another revelation of the pilot study was the fact that it took the students an average of thirty minutes to complete the questionnaire. This time was then used for the actual study. Finally, the pilot study revealed that the best approach for conducting the survey would be to get the students to complete the survey during class time, as opposed to letting them take it home and bringing it back during the next class session. By conducting the survey in class, the researchers were able to collect the completed questionnaires immediately, thus ensuring a much higher response rate in the actual study.

As specified in an earlier section of this paper, moral competence (MC) from an Islamic perspective is a product of two components: moral action in line with the Qur' an and Sunnah (MA) and moral intention to please Almighty Allah alone (MI). Participating students were asked to resolve each scenario by stating the action they would advice their friend to take (MA), and providing a reason for that advice (MI). If a student's MA corresponded with the model MA, a score of 1 was given; if it did not, a score of 0 is given. The same rule applied for MI ( 1 for the correct reason, and 0 for incorrect reason). For each scenario, a student's $\mathrm{MC}=\mathrm{MA}$ * MI. For a student to have a score for any scenario, both MA and MI must have corresponded with the model answers, otherwise he or she scored 0 for that scenario. Scores for each scenario were added to provide an overall MC score for each student; MC scores could range from a minimum of " 0 " to a maximum of "10"

Measuring the moral competencies of thirdyear Muslim accounting students at USIM

Following the approach adopted in the pilot study, all sections of a compulsory third-year accounting course were surveyed using
MAMOC. 79 third-year students completed the questionnaire.

\section{Results and Discussion}

This section of the paper presents the research findings and their implications. The descriptive statistics of the study's respondents is presented first. The students' mean MC scores are presented next, and this is followed by a more detailed analysis of their performance for each scenario and the implication vis-a-vis their future as Malaysian accountants. To provide insight as to the performances of the students overall vis-a-vis their moral competencies, as well as their performance for each scenario, USIM's undergraduate grading system was utilized. The lowest grade for a pass is a grade of "C". The grading system is presented in Table 1 :

Table 1: USIM Undergraduate Grading System

\begin{tabular}{llll}
\hline Percentage & Letter & Quality & Remark \\
Score & Grade & $\begin{array}{l}\text { Point } \\
\text { Equivalent }\end{array}$ & \\
& & &
\end{tabular}

\begin{tabular}{llll}
\hline $\mathbf{8 5 - 1 0 0}$ & A & 4.00 & Excellent \\
$\mathbf{7 5 - 8 4}$ & A- & 3.67 & Extremely \\
& & & Good \\
$\mathbf{7 0 - 7 4}$ & B+ & 3.33 & Very Good \\
$\mathbf{6 5 - 6 9}$ & B & 3.00 & Good \\
$\mathbf{6 0 - 6 4}$ & B- & 2.67 & Fairly \\
& & Good \\
$55-59$ & C & 2.33 & Satisfactory \\
$50-54$ & C- & 2.00 & Quite \\
& & & Satisfactory \\
$45-49$ & D & 1.67 & Poor \\
$\mathbf{4 0 - 4 4}$ & D- & 1.33 & Very Poor \\
$35-39$ & E & 1.00 & Extremely \\
& & & Poor \\
$0-34$ & F & 0.00 & Failed \\
\hline
\end{tabular}

Moral Competencies of Third-year Muslim Accounting Students at USIM

Tables 2 and 3 presents information about the study's sample via descriptive statistics: The 79 students sampled had an average age of 22.04 years, and females made up $70.9 \%$ of the sample, with 56 out of the 79 being females. 
Table 4 presents the mean moral competency of the 79 third-year Muslim accounting students surveyed at USIM. The students' had a mean moral competency of 5.34 out of a maximum of 10; This is a percentage score of $53.4 \%$, which according to Table 1 means that the third-year accounting students surveyed earned a moral competence grade of "C-" which USIM considers "Quite satisfactory", but interestingly is below the " $\mathrm{C}$ " grade necessary for passing a course at the accounting department. The implication of this statistic is that according to USIM's own grading standards, their third-year class is not at an acceptable level of moral competence needed to deal with the inevitable moral dilemmas in the work place.

The Malaysian government's 2012 mandate that all universities are to develop morally competent accountants is not currently being achieved by USIM's accounting department, based on the university's own grading system. Additionally, the department is falling below its stated aim of producing accounting professionals that "observe ethical norms in their conduct" (Bachelor of Accounting Programme Description, n.d.). In light of these revelations, it is very important for the department to review the ethical content of its curriculum, and hold targeted discussions with the academic staff in order to come up with strategies to address this important task of enhancing the moral competencies of these students before they graduate in a year's time. An examination of how well the students performed vis-a-vis each scenario will shed more light on the specific qualities the department needs to focus on developing amongst their accounting students.

Table 5 below presents the students' mean moral competence scores for each scenario. It can be observed that the students only "passed" four out of the ten scenarios based on USIM's grading system. Further discussions on their performance for each scenario are discussed below.

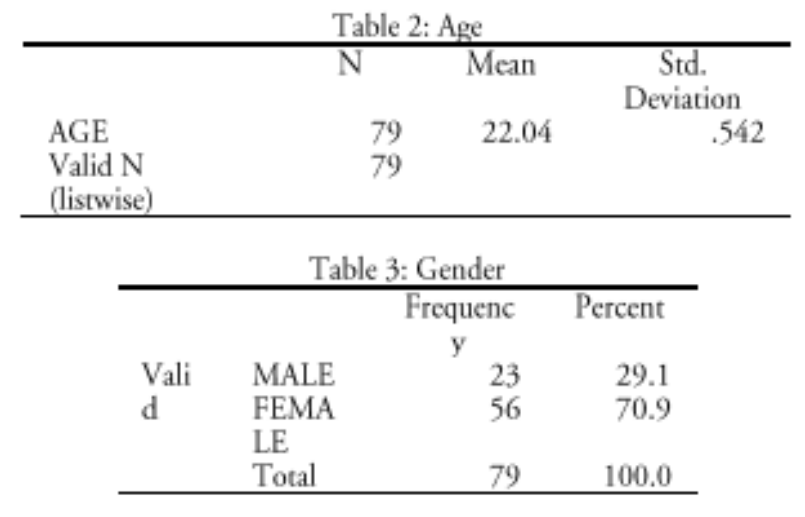

Table 4: Mean Moral Competence Score

\begin{tabular}{|c|c|c|}
\hline & $\overline{\mathrm{N}}$ & Mean \\
\hline $\begin{array}{l}\text { MC } \\
\text { Score }\end{array}$ & 79 & 5.34 \\
\hline
\end{tabular}

Table 5: Mean Moral Competence scores for each scenario

\begin{tabular}{|c|c|c|c|c|}
\hline Scenario & $M$ & $\mathrm{G}$ & $\mathrm{R}$ & $\mathrm{S}$ \\
\hline Job selection & .13 & $\bar{F}$ & Failed & Fail \\
\hline $\begin{array}{l}\text { Professional } \\
\text { Conduct }\end{array}$ & .92 & A & Excellent & Pass \\
\hline $\begin{array}{l}\text { Trustworthines } \\
s\end{array}$ & .67 & B & Good & Pass \\
\hline $\begin{array}{l}\text { Professional } \\
\text { Competence } \\
\text { and Diligence }\end{array}$ & .51 & $\mathrm{C}$ & $\begin{array}{c}\text { Quite } \\
\text { satisfacto } \\
\text { ry }\end{array}$ & Fail \\
\hline $\begin{array}{l}\text { Avoiding } \\
\text { interest }\end{array}$ & .19 & $\mathrm{~F}$ & Failed & Fail \\
\hline $\begin{array}{l}\text { Avoiding } \\
\text { gambling }\end{array}$ & .44 & D- & $\begin{array}{l}\text { Very } \\
\text { poor }\end{array}$ & Fail \\
\hline $\begin{array}{l}\text { Avoiding } \\
\text { contact with } \\
\text { the opposite sex }\end{array}$ & .57 & C & $\begin{array}{c}\text { Satisfact } \\
\text { ory }\end{array}$ & Pass \\
\hline Objectivity & .80 & A- & $\begin{array}{l}\text { Extremel } \\
\text { y good }\end{array}$ & Pass \\
\hline Confidentiality & .58 & C & $\begin{array}{l}\text { Satisfact } \\
\text { ory }\end{array}$ & Fail \\
\hline Final choice & .54 & $\mathrm{C}$ & $\begin{array}{c}\text { Quite } \\
\text { satisfacto } \\
\text { ry } \\
\end{array}$ & Fail \\
\hline
\end{tabular}

Section 2: Choosing your dream job

Table 5 above shows that only $13 \%$ of the students were able to understand that none of the five jobs offered were acceptable from an Islamic perspective. According to USIM's grading system, the students scored a failing grade of " $F$ " in this scenario. In assessing the responses of the majority of the students who 
failed to successful resolve this scenario, it was observed that salary was the major motivation for job selection, closely followed by personal interest.

This statistic has grave implications regarding the moral competencies of Malaysia's future Muslim accountants. This is because, working in an organization that is involved in haram (prohibited) activities has devastating spiritual effects on the soul of a Muslim.

All earnings from such a job are considered haram, and thus any usage of those earnings are also considered haram. In fact, choosing to work in a haram organization negates all the other eight qualities included in the profile of a morally competent accountant. Being trustworthy and professionally diligent whilst working in a haram organization has no value in the sight of Allah, as the foundation is rotten, and Allah only accepts what is pure. The following hadith provides a clear description of the grave consequence of choosing a haram job: Narrated Abu Hurairah: that the Messenger of Allah (PBUH) said: "O you people! Indeed Allah is Tayyib (good) and he does not accept but what is good. And indeed Allah ordered the believers with what He ordered the Messengers. $\mathrm{He}$ (PBUH) said: 'O you Messengers! Eat of the good things and do righteous deeds. Verily I am well acquainted with what you do (Q23:51).' And He said: 'O you who believe! Eat from the good things We have provided you (Q2:172).' He said: "And he mentioned a man: 'Who is undertaking a long journey, whose hair is dishevelled and he is covered with dust. He raises his hands to the heavens and says: "O Lord! O Lord!" Yet his food is from the unlawful, his drink is from the unlawful, his clothing is from the unlawful, and he was nourished by the unlawful. So how can that be accepted?'" (Jami at-Tirmidhi, Book 47, Hadith 3257).
This statistic also serves as a much-needed reminder for the accounting department at USIM. The department has claimed as its mission statement, the development of accountants inculcated with Islamic values; However, close to $90 \%$ of their third-year class do not possess the fundamental moral competence to understand that they must work in an organization approved by Allah to be successful in this world and the next. It is hoped that this will spur the department to make sure that these students are inculcated with this fundamental aspect of Islamic moral competence before they graduate.

Section 3: Living your dream job

Scenario 1: Professional Conduct

Table 5 above shows that unlike in the "choosing your dream job" scenario where the students' had a failing grade, they did much better regarding resolving the professional conduct scenario, with a percentage score of $92 \%$ corresponding to an "A" grade which is rated as "excellent". The implication of this statistic is that the vast majority of USIM's thirdyear accounting students understood that a job was a trust and that Allah would hold them accountable for fulfilling that trust. For this reason, they understood that they had to strictly follow the working hours stipulated by the organization in order to fulfil that trust. Additionally, it showed that they were aware of the fact that as future professional Muslim accountants, they have a duty to maintain a high level of conduct as they discharge their duties. Almighty Allah says: "Indeed, Allah commands you to render trusts to whom they are due and when you judge between people to judge with justice. Excellent is that which Allah instructs you. Indeed, Allah is ever Hearing and Seeing" (An-Nisa: 58). 


\section{Scenario 2: Trustworthiness}

Table 5 above reveals that $67 \%$ of the students showed signs of trustworthiness by correctly resolving this scenario. This earned them a "B" grade and a "good" performance regarding this quality. The students who successfully resolved this scenario revealed an understanding of the fact that they had a moral obligation to avoid the manipulation of financial statements despite external pressure from superiors. As Muslim accountants, accountability is first and foremost to Allah above all else: That is only Satan who frightens [you] of his supporters. So fear them not, but fear Me, if you are [indeed] believers (Ali 'Imran: 175).

Scenario 3: Professional Competence and Diligence

Table 5 above reveals that only $51 \%$ of the students correctly resolved this scenario, thus earning them a "quite satisfactory" grade of "C". $49 \%$ of the students put their personal interests over their diligence as accountants by advising their friend in the scenario to place RM20 of his own money into the company account to rectify a discovered irregularity, so as to make a flight for a holiday; The justification for this choice was that the amount was immaterial. Islam holds Muslims to a much higher standard, and regardless of the amount of the irregularity, the correct resolution that reflected professional competence and diligence was for the accountant to go through all the company transactions again so as to identify and rectify the irregularity. This is what his job entails and as a Muslim accountant, he is obligated to fulfil. "O you who have believed, fulfil [all] obligations..." (Al-Ma'idah:1).

Scenario 4: Avoiding Interest

Table 5 above shows that a mere $19 \%$ of the students correctly resolved this scenario, which earns a grade of "F" and a remark of "failed". Only 15 out of the 79 students understood that dealing with interest is strictly forbidden in Islam.

USIM's accounting department has significant room for improving the students' moral competence regarding dealing with interest, as it is a major sin with severe consequences: "O you who have believed, fear Allah and give up what remains [due to you] of interest, if you should be believers. And if you do not, then be informed of a war [against you] from Allah and His Messenger. But if you repent, you may have your principal - [thus] you do no wrong, nor are you wronged (Al-Baqarah: 278-279).

\section{Scenario 5: Avoiding gambling}

Table 5 above reveals that only $44 \%$ of the students correctly resolved this scenario, thus earning a "very poor" grade of "D-". The students' responses showed that $56 \%$ of them did not realize that any form of gambling is prohibited in Islam, even if it is done supposedly to encourage a virtuous behaviour, as was the case in the scenario. "O you who have believed, indeed, intoxicants, gambling, [sacrificing on] stone altars [to other than Allah], and divining arrows are but defilement from the work of Satan, so avoid it that you may be successful" (Al-Maidah: 90).

Scenario 6: Avoiding physical contact with the opposite sex (non-mahram)

Table 5 above reveals that $57 \%$ of the students correctly resolved the scenario, earning a grade of "C" which is deemed "satisfactory". This statistic is important due to the fact that in Islam, men and women who are unrelated (nonmahram) are not allowed to have any physical contact whatsoever. This is evidenced by the following hadith: Ma'qil ibn Yassaar said: the Messenger of Allah (PBUH) said: "For one of you to be stabbed in the head with an iron needle is better for him than that he should 
touch a woman who is not permissible for him." (At-Tabarani, al-Kabeer, 486).

Most of the students who incorrectly resolved the scenario actually understood that Muslim men and women who are unrelated are not allowed physical contact, no matter how benign. However, they had the misconception that as long the woman wore gloves, it was acceptable. Renowned Islamic scholar, Shaykh Abd-Allaah ibn Jibreen clarifies this misconception as follows: " It is not permissible for a woman to shake hands with a non-mahram man even if she is wearing gloves or she shakes hands from under a cloth or abayah. All of that counts as shaking hands even if there is some kind of barrier" (14044: Is a woman sinning if she shakes hands with a man?, n.d.). Some other students felt it was okay for a Muslim woman to shake a non-mahram man so as not to offend his sensibilities. This is of course not acceptable Islamically; Muslims must never please people whilst displeasing their Creator.

\section{Scenario 7: Objectivity}

Table 5 above reveals that $80 \%$ of the students correctly resolved this scenario, thus receiving an "extremely good" grade of "A". 63 out of the 79 students understood that as Muslim accountants, they have to be objective in discharging their duties; There is no room for bias as an accountant. This is a comforting statistic regarding Malaysia's future Muslim accountants, considering that in Islam, objectivity is synonymous with justice and is a very important virtue: $O$ you who have believed, be persistently standing firm for Allah, witnesses in justice, and do not let the hatred of a people prevent you from being just. Be just; that is nearer to righteousness. And fear Allah; indeed, Allah is Acquainted with what you do (AlMaidah: 8).

\section{Scenario 8: Confidentiality}

Table 5 above reveals that $58 \%$ of the students correctly resolved this scenario, earning them a "C" grade which is regarded as "satisfactory". The scenario was designed to test the students' understanding regarding the limits of confidentiality as Muslim accountants. Muslim accountants are bound to keep the secrets of the company as long as their actions are good; once they venture into systematic evil (cooking the books in this scenario), their loyalty ends and they have to become whistleblowers so as to safeguard the rest of society from the evil consequences of the company's actions: "... And cooperate in righteousness and piety, but do not cooperate in sin and aggression. And fear Allah; indeed, Allah is severe in penalty" (AlMaidah:2). USIM's accounting department should ensure that students understand that their loyalty as accountants is first and foremost to their Creator; Company actions done in line with His commands are protected, whilst those that continually violate His commands and harm society, are exposed: "You are the best nation produced [as an example] for mankind. You enjoin what is right and forbid what is wrong and believe in Allah" (Ali-Imran: 110).

\section{Scenario 9: Final Decision}

Table 5 above shows that $54 \%$ of the students correctly resolved this scenario, thus earning a "quite satisfactory" grade of "C-". The students were asked if they would still work in the company considering their experiences in all the previous scenarios. The students who successfully resolved this scenario understood that as Muslims, they were not allowed to stay in an environment where evil activities are predominant. The following verse explains this fact: And it has already been revealed to you in the Book (this Quran) that when you hear the Verses of Allah being denied and mocked at, then sit not with them, until they engage in a 
talk other than that; (but if you stayed with them) certainly in that case you would be like them. Surely, Allah will collect the hypocrites and disbelievers all together in Hell" (An-Nisa: 140). As-Sa'di, the renowned commentator of the Noble Quran, explains this verse as follows: "That is, if you sit with them in the situation mentioned then you are like them, because you have approved of their disbelief and mockery, and the one who approves of sin is like the one who does it. The point is that the one who attends a gathering in which Allah is disobeyed has an individual obligation to denounce them, if he is able to do so, or to get up and leave, if he is not able to denounce it" (Tafseer As-Sa'idi, p210).

The accounting department at USIM must make significant efforts to instil in their students the fact that as Muslim accountants, it is not permissible to stay in an organization that continually violates Allah's commands in its activities. This toxic environment degrades a person's faith and endangers his success in this life and the next

\section{Conclusion}

Two decades of financial scandals have seriously damaged the credibility of accountants as guardians of financial information. To repair this credibility, universities have been identified as crucial to the development of morally competent accountants for the future. In 2012, the Malaysian government joined this crusade through the release of a blueprint to revolutionize the Malaysian educational system. One of the key mandates of this blueprint was for Malaysian educational institutions to produce morally competent professionals. This study sought to assess the progress of Malaysian universities in meeting this important mandate by evaluating the moral competencies of thirdyear accounting students enrolled at the
International Islamic University Malaysia (USIM).

As USIM is an Islamic university, and all its third-year students are Muslims, an instrument was developed through a collaboration with Islamic accounting and Fiqh Muamalat scholars to measure the moral competencies of these students from a wholly Islamic perspective. Islam's two primary sources of guidance, The Noble Quran and Sunnah were relied upon to develop this instrument. The instrument called Muslim Accountant Moral Competency Test (MAMOC) contained ethical scenarios to measure nine qualities required for a morally competent Muslim accountant; 79 third-year students were surveyed using MAMOC.

The results of the survey revealed that according to USIM's own grading system, the current crop of third-year accounting students were not morally competent enough to deal with the inevitable moral dilemmas they would face in the work place. The students were particularly weak regarding selecting an Islamicallyappropriate place to work as well as avoiding interest-based transactions. On the bright side, the students showed a very clear understanding of the importance of conducting themselves professionally and objectively as accountants.

This implications of these results is that at the moment, USIM's accounting department is not meeting the government's mandate to produce morally competent professionals. The department has to re-examine its current curriculum as to its ethics coverage, particularly regarding qualities that the students scored very low on. The department has as its stated mission the production of accounting graduates "who embrace Islamic values" (Bachelor of accounting programme description, n.d.). It must make sure it does all it can to fulfil this noble mission.

The main limitation of this study is that it only focuses on one Islamic university in 
Malaysia, and for this reasons its findings cannot be generalized. Future studies should include more universities so as to assess their moral credentials.

\section{References}

Abdulmohammadi, M. J., \& Baker, C. R. (2007). The relationship between moral reasoning and plagiarism in accounting courses: A replication study. Issues in Accounting Education, 22(1), 45-55.

Abu Bakar, N., Ismail, S., \& Mamat, S. (2010). Will Graduating Year Accountancy Students Cheat in Examination? A Malaysian Case. International Education Studies, 3(3), 145-152.

Accounting, Auditing, and Governance Standards for Islamic Financial Institutions, 1420H-1999, Bahrain: AAOIFI

Al-Ansari, E. M. (2002). Effects of gender and education on the moral reasoning of Kuwait university students. Social Behaviour and Personality: an international journal, 30(1), 75-82.

Altmyer, D., Yang, S. P., Schallenkamp, K., \& DeBeaumont, R. (2011). Student ethical awareness and business program matriculation: Evidence from the US. Business Education \& Administration, 3(1), 41-49.

Bayou, M. E., Reinstein, A., \& Williams, P. F. (2011). To tell the truth: A discussion of issues concerning truth and ethics in accounting. Accounting, Organizations and Society, 36(2), 109-124.

Bosco, S. M., Melchar, D. E., Beauvais, L. L., \& Desplaces, D. E. (2010). Teaching business ethics: The effectiveness of common pedagogical practices in developing students' moral judgment competence. Ethics and Education,5(3), 263-280.

Chafi, R. M. (2013). The Effect of Accounting Education on Occupational Ethics. Retrieved from http://tjeas.com/wpcontent/uploads/2013/10/3468-3474.pdf

Chaganti, V. K. (2012). A Study of Moral Judgment Competence among Indian Students. FedUni Journal of Higher Education, 2(1), 53-60.

Clipa, O., \& Iorga, A. M. (2013). The role of school-family partnership on moral development. Procedia-Social and Behavioral Sciences, 76, 197-203.

Dellaportas, S. (2006). Making a difference with a discrete course on accounting ethics. Journal of Business Ethics, 65(4), 391-404.

Doyle, E., \& O'Flaherty, J. (2013). The impact of education level and type on moral reasoning. Irish Educational Studies, 32(3), 377-393.

Eid, M. (2012). Paula S. Tompkins: Practicing Communication Ethics: Development, Discernment, and Decision Making. Journal of business ethics, 1-2.

Fontaine, M (2012). Integrating Narrative Fiction with Business Ethics to Enhance Moral Reasoning Applying an Ethical Framework and Case Discussion Instructional Model. Retrieved from http://aripd.org/journals/rcbr/Vol_1_No_ 1_December_2012/1.pdf

Freedman, D., Pisani, R., \& Purves, R. (2007). Statistics (International Student Edition). WW Norton \& Co, New York. 
Halgren, K.A. (2012). Computing Inter-Rater Reliability for Observational Data: An Overview and Tutorial. Tutor Quants Methods Psychol., 8(1), 23-34.

Holmes, K., Marriott, L., \& Randal, J. (2012). Ethics and experiments in accounting: A contribution to the debate on measuring ethical behaviour. Pacific Accounting Review, 24(1), 80-100.

Kavathatzopoulous, I. (2012). Assessing and Acquiring Ethical Leadership Competence. In Leadership through the Classics (pp. 389-400). Springer Berlin Heidelberg.

Kohlberg, L. (1958). The development of modes of moral thinking and choice in the years 10 to 16 . University of Chicago.

Liaquat, A. W., Mall, A., \& Shah, S. A. (n.d.). Religiosity, Education and Moral Judgment: A Comparative Study of University, College And Madrasah Students Of Pakistan. Retrieved from uni-konstanz.de

Malaysia Education Blueprint 2013-2025 (2012). Develop values-driven Malaysians. Retrieved from http://www.moe.gov.my/userfiles/file/PPP /Preliminary-Blueprint-Eng.pdf

Malaysian Institute of Accountants (2012). NIP Philosophy. Retrieved from http://www.iim.org.my/en/falsafah-pin

Malaysian Institute of Accountants (2012). NIP Philosophy. Retrieved from http://www.iim.org.my/en/falsafah-pin

May, D. R., \& Luth, M. T. (2013). The effectiveness of ethics education: A quasiexperimental field study. Science and engineering ethics, 1-24.

Montgomery, D., \& Walker, M. (2012). Enhancing Ethical Awareness. Gifted Child Today, 35(2), 95-101.
Özdemir, F. K., Şahin, Z. A., Dayapoğlu, N., \& Alemdar, D. K. (2015). The Effect Of University Education On Moral Judgment Competence Of Nursing Students In Turkey. Retrieved from http://www.researchgate.net/profile/Dile k_Alemdar/publication/278667873

Padia, N., \& Maroun, W. (2012). Ethics in business: The implications for the training of professional accountants in a South African setting. African Journal of Business Management, 6(32), 9274-9278

Phelan, C., \& Wren, J. (2006). Exploring reliability in academic assessment.UNI Office of Academic Assessment.

Pleban, R. J., Graves, T. R., Miller, M. L., Donigian, A. M., Branciforte, J. V., \& Matthews, M. D. (2011). Evaluating a Problem-Based Learning Strategy for Enhancing Ethical Awareness in Negotiation. Army Research Institute for the Behavioral And Social Sciences Fort Benning Ga Research Unit.

Rest, J. (1974). Judging the Important Issues in Moral Dilemmas- An Objective Measure of Development. Developmental Psychology, 10(4), 491-501.

Rest, J. R. (1986). Moral development: Advances in research and theory. Praeger Publishers.

Rest, J. R. (1989). Development in judging moral issues. U of Minnesota Press

Saat, M., Porter, S., \& Woodbine, G. (2010). The effect of ethics courses on the ethical judgement-making ability of Malaysian accounting students. Journal of Financial Reporting and Accounting, 8(2), 92109. 
Saat, M., Stacey, P., \& Gordon, W. (2009). Does religiosity influence ethical sensitivity? An investigation on Malaysian future accountants. Malaysian Accounting Review, 8(2), 17-41.

Savulescu, J., Crisp, R., Fulford, K. W., \& Hope, T. (1999). Evaluating ethics competence in medical education. Journal of Medical Ethics, 25(5), 367-374.

Schillinger, M. (2006). Learning environment and moral development: How university education fosters moral judgment competence in Brazil and two Germanspeaking countries (Doctoral dissertation, Aachen: Shaker).

Schmidt, C. D., Davidson, K. M., \& Adkins, C. (2013). Applying what works: A case for deliberate psychological education in undergraduate business ethics.Journal of Education for Business, 88(3), 127-135.

Self, D.J., Stramaski, A.J. \& Engelhardt, J. A. (2013). Evaluation Of Changes In Moral Reasoning Skills In An Interprofessional Healthcare Ethics Course.

Shah, A. A. (2004). Self-Religiosity, Father's Attitude and Religious Education in the Moral behaviour of Adolescents. Psychology of Developing Societies, 16(2), 187-207.

Sullivan, G. R. (2004). Enhancing Public Trust in the Accounting Profession Using Professional Judgment Rather Than Personal Judgment in Resolving Accounting Ethics

Dilemmas (Doctoral dissertation, Regent University).
Thiel, C. E., Connelly, S., Harkrider, L., Devenport, L. D., Bagdasarov, Z., Johnson, J. F., \& Mumford, M. D. (2013). Case-based knowledge and ethics education: Improving learning and transfer through emotionally rich cases. Science and engineering ethics, 19(1), 265-286.

Thomas, S. (2012). Ethics and Accounting Education. Issues in Accounting Education, 27(2), 399-418.

Titus, C., Zoltowski, C. B., Huyck, M., \& Oakes, W. C. (2011). The Creation of Tools for Assessing Ethical Awareness In Diverse Multi-Disciplinary Programs. Retrieved from https://sharepoint.ecn.purdue.edu/doe/Me ntoring/Shared\%20Documents/1833.pdf

Wortel, E., \& Bosch, J. (2011). Strengthening Moral Competence: A 'Train The Trainer'course On Military Ethics. Journal Of Military Ethics, 10(1), 17-35.

Yeşilada, B., Noordijk, P., \& Webster, C. (2009). Religiosity and social values of the Cypriots. Social Compass, 56(1), 15-34.

Yunus, S., \& Abdul Rashid, M.Z. (2011). The Propensity of Applying Principled-Moral Reasoning Among Undergraduate Business Students in Malaysia. Canadian Journal on Scientific and Industrial Research, 2(8), 279-289. 